\title{
A new species of Anchoviella Fowler, 1911 (Clupeiformes: Engraulidae) from the Amazon basin, Brazil
}

\author{
Marina V. Loeb
}

\begin{abstract}
Anchoviella juruasanga is described from the drainages of rios Negro, Madeira, Tapajós, Trombetas, Tocantins, and Jari, in the Amazon basin, Brazil. The new species is distinguished from its congeners by having a short upper jaw, with its posterior tip extending between the verticals through anterior and posterior margins of the pupil ( $v s$. posterior tip of upper jaw extending beyond the vertical through posterior margin of the pupil). Anchoviella juruasanga is also distinct from other strictly freshwater Amazonian species of the genus by the distance from tip of snout to posterior end of upper jaw between 8 and $11 \%$ in standard length (vs. 14\% or more in A. alleni, A. carrikeri, A. guianensis, and A. jamesi). The anal-fin origin slightly posterior to or at the vertical through the base of the last dorsal-fin ray further distinguishes the new species from $A$. alleni (anal-fin origin posterior to the vertical through the last anal-fin ray by at least $14 \%$ of head length) and $A$. jamesi (anal-fin origin anterior to the vertical through the last anal-fin ray). An identification key for the Amazonian species of Anchoviella, including marine and estuarine species known to occur in the lower portion of the basin, is presented.
\end{abstract}

Anchoviella juruasanga é descrita das drenagens dos rios Negro, Madeira, Tapajós, Trombetas, Tocantins e Jari, na bacia Amazônica, Brasil. A nova espécie distingue-se de suas congêneres pela presença da maxila superior curta, com sua extremidade posterior estendendo-se entre as verticais que passam pelas margens anterior e posterior da pupila ( $v s$. extremidade posterior da maxila superior estendendo-se além da vertical que passa pela margem posterior da pupila). Anchoviella juruasanga também distingue-se das demais espécies Amazônicas estritamente dulcícolas do gênero pela distância da ponta do focinho à extremidade posterior da maxila superior entre 8 e $11 \%$ do comprimento padrão (vs. $14 \%$ ou mais em A. alleni, A. carrikeri, A. guianensis e A. jamesi). A origem da nadadeira anal em uma região ligeiramente posterior ou na vertical que passa pela base do último raio da nadadeira dorsal também distingue a nova espécie de $A$. alleni (origem da nadadeira anal posterior à vertical que passa pelo último raio da nadadeira anal por no máximo $14 \%$ do comprimento da cabeça) e $A$. jamesi (origem da nadadeira anal anterior à vertical que passa pelo ultimo raio da nadadeira anal). É apresentada uma chave de identificação para as espécies Amazônicas de Anchoviella, incluindo espécies marinhas e estuarinas conhecidas por ocorrer nas porções baixas da bacia.

Key words: Anchovies, Engraulinae, Freshwater fish, Systematics, Taxonomy.

\section{Introduction}

Anchoviella Fowler, 1911 comprises small to medium sized fishes (3-14 cm standard length) of marine, estuarine, or freshwater habits distributed in South, Central, and North America. According to Whitehead et al. (1988) the genus is distinguished in the Engraulidae by a body slightly compressed, the presence of numerous elongate gill rakers (usually more than 15 on the lower branch of the first gill arch) and a short upper jaw (not extending posteriorly to the vertical through the anterior margin of the opercle). Members of the Engraulidae, which includes approximately 140 species, are typically schooling coastal fishes commonly known as anchovies (English) or "manjubas" in the Brazilian Portuguese (Nelson, 2006; Di Dario, 2009).
Jordan \& Seale (1926) recognized 18 valid species of Anchoviella. Anchoviella jamesi (Jordan \& Seale, 1926) and A. balboae (Jordan \& Seale, 1926), which are species of anchovies with a small mouth and a rounded posterior end of the upper jaw, were included in the genus Amplova by Jordan \& Seale (1926). Hildebrand (1943) concluded that Jordan \& Seale's (1925) classification was unsatisfactory. He combined Amplova and Anchoviella in an expanded genus Anchoviella. Anchoviella manamensis Cervigón, 1982 and A. perezi Cervigón, 1987, both from rio Orinoco in Venezuela (Cervigón, 1982), are the most recently described valid species of the genus.

Anchoviella has not been thoroughly reviewed for more than 50 years, and the number of currently valid species of the genus is still debatable. Whitehead et al. (1988), which 
presented the most recent comprehensive review of the Engraulidae, recognized 15 valid species of Anchoviella. Eschmeyer \& Fricke (2012), on the other hand, recognized 18 valid species of the genus. In spite of discrepancies in those numbers, Whitehead et al. (1988) and Eschmeyer \& Fricke (2012) recognized the validity of four strictly freshwater Amazonian species of Anchoviella: A. alleni (Myers, 1940), A. carrikeri Fowler, 1941, A. guianensis (Eigenmann, 1912), and A. jamesi (Jordan \& Seale, 1926). Anchoviella nattereri (Steindachner, 1880), which supposedly inhabits the lower (probably estuarine) portion of the Amazon basin, is known only from the original description (Whitehead et al., 1988). The species is sometimes recognized as valid (e.g. Kullander \& Ferraris, 2003; Eschmeyer \& Fricke, 2012; Menezes \& Figueiredo, 2003), but Whitehead et al. (1988: 337) considered it as a possible senior synonym of the marine and estuarine A. lepidentostole (Fowler, 1911). Recently, Loeb (2009) considered $A$. nattereri as a nomen dubium.

During a recent review of the South American freshwater species of Anchoviella (Loeb, 2009), new species from the Amazon basin were discovered. One of those species is described herein. An identification key for the Amazonian species of Anchoviella, including coastal species known to occur in the lower portion of the basin, is also presented.

\section{Material and Methods}

Measurements and counts were taken according to Whitehead (1985) with the following modifications: caudal peduncle depth, measured at the origin of caudal fin; pelvic-fin length, measured from the base of the fin to the posterior tip of the longest pelvic-fin ray; prepelvic, prepectoral and preanal length, measured from tip of snout to the origin of the respective fin; pupil diameter, measured as the horizontal distance between pupil margins; lower jaw length, measured as the distance between anterior and posterior margins of the lower jaw; interorbital width, corresponding to the shortest distance between the orbits in dorsal view; length of pectoral and pelvic axillary scales, measured as the distance between the anterior and posterior margins of the axillary scale. Measurements and counts were taken in 41 type specimens (including holotype) on the left side of the specimen. Standard Length (SL) is expressed in $\mathrm{mm}$ and other measurements are expressed as either percentage of SL or Head Length (HL). Vertebral counts, presented in Table 1, are based on two cleared and stained specimens prepared according to Taylor \& van Dyke (1985). Comparative material examined of the genus includes Anchoviella alleni, A. carrikeri, A. guianensis, and A. jamesi (the four valid Amazonian freshwater species of Anchoviella), two recently recognized but yet undescribed Amazonian species of Anchoviella (Loeb, 2009), and also A. vaillanti (Steindachner, 1908), from the São Francisco basin (Whitehead et al., 1988). Anchoviella brevirostris (Günther, 1868), A. cayenensis (Puyo, 1946), and A. lepidentostole, which are coastal marine species known to occur in the lower portion of the Amazon basin, were also examined.
Institutional abbreviations are ANSP, Academy of Natural Sciences, Philadelphia, PA; INPA, Instituto Nacional de Pesquisas da Amazônia, Manaus, AM; MZUSP, Museu de Zoologia da Universidade de São Paulo, SP; MNRJ, Museu Nacional, Universidade Federal do Rio de Janeiro, RJ; MPEG, Museu Paraense Emílio Goeldi, Belém, PA.

\section{Results}

\section{Anchoviella juruasanga, new species Figs. 1-2}

Holotype. MZUSP 109249, 42.4 mm SL. Brazil, Pará, rio Trombetas, upstream from mouth of Lago do Jacaré at Reserva Biológica de Trombetas, $01^{\circ} 20^{\prime} \mathrm{S} 56^{\circ} 51^{\prime} \mathrm{W}, 2$ Aug 1979 , R. M. C. Castro.

Paratypes. ANSP 192138 (20, 42.7-48.1mm SL), MNRJ 39086 (20, 42.0-49.8 mm SL), MPEG 22814 (20, 44.0-48.5 mm SL), MZUSP 15831 (243, 42.0-52.8 mm SL), all collected with holotype. INPA 7104 (30, 26.1-42.3 mm SL), Pará, rio Tapajós, near mouth of rio Cupari, 03³6'22.79”'S 55¹9'13.76”W, 26 Oct 1991, L. Rapp Py-Daniel \& J. Zuanon. MZUSP 31422 (1, 39.2 mm SL), Rondônia, rio Madeira at Calama, $08^{\circ} 03^{\prime} \mathrm{S} 62^{\circ} 53^{\prime} \mathrm{W}, 9 \mathrm{Dec} 1980$, M. Goulding. MZUSP 52015 (2, 23.1-26.7 mm SL), Rondônia, rio Machado near its mouth, 08 $04^{\prime}$ 'S 62 4'W, 21 Nov 1970, Expedição Permanente à Amazônia. MZUSP 85397 (5, 21.90-25.80 mm SL), Rondônia, rio Machado near its mouth, 21 Nov 1975, Expedição Permanente à Amazônia.

Non-type specimens examined. MZUSP 8554 (1, $33.73 \mathrm{~mm}$ SL), Pará, Santarém, rio Tapajós, $02^{\circ} 25^{\prime}$ 'S, 544' W, Dec 1967, Expedição Permanente à Amazônia. MZUSP 9228 (2, 19.77-19.87 mm SL), Pará, Santarém, rio Maicá, $02^{\circ} 35^{\prime}$ 'S 542'' W, 19-27 Oct 1971, Expedição Permanente à Amazônia. MZUSP 9420 (5, 38.69-40.83 mm SL), Pará, Santarém, rio Tapajós, $02^{\circ} 25^{\prime}$ 'S 544ㄴ'W, 10 Jan 1968 , Expedição Permanente à Amazônia. MZUSP 18155 (3, 37.47-39.96 mm SL), Pará, Jatobal, rio Tocantins, 043'ㅅ $49^{\circ} 39^{\prime} \mathrm{W}, 17$ Nov 1970, Expedição Permanente à Amazônia. MZUSP 28049 (2, 12.4223.27 mm SL) Amazonas, Ayrão Velho, rio Negro, north of ecological reserve of Anavilhanas, 06 Nov 1982, L. P. S. Portugal. MZUSP 29096 (5, 21.82-23.8 mm SL), Roraima, Marará, rio Branco, 01 3030'S $61^{\circ} 16^{\prime} \mathrm{W}, 26$ Oct 1979, M. Goulding. MZUSP 29121 (19, 24.29$30.86 \mathrm{~mm} \mathrm{SL}$ ), and MZUSP 29122 (88, 73, 20.22-26.12 mm SL), Roraima, Marará, rio Branco, 01³0'S 611'' W, 26 Oct 1979, M. Goulding..MZUSP 29123 (253, 24.33-32.41 mm SL), Rondônia, rio Madeira, at the junction with rio Machado, $08^{\circ} 04^{\prime} \mathrm{S}, 62^{\circ} 54^{\prime} \mathrm{W}, 15$ Dec 1980, M. Goulding. MZUSP 73533 (1, 19.22 mm SL), Roraima, Marará, rio Branco, $01^{\circ} 30^{\prime} \mathrm{S} 61^{\circ} 16^{\prime} \mathrm{W}, 28$ Oct 1979 , M. Goulding. MZUSP 74315 (57, 18.94-22.21 mm SL), Roraima, Caracaraí, rio Branco near its mouth, $01^{\circ} 20^{\prime}$ S $61^{\circ} 50^{\prime} \mathrm{W}, 12$ Nov 1979, L. P. S. Portugal. MZUSP 85218 (3, 21.81-28.99 mm SL), Rondônia, rio Machado near its mouth, $08^{\circ} 04^{\prime}$ 'S 62 $2^{\circ} 54^{\prime} \mathrm{W}, 21$ Nov 1975, Expedição Permanente à Amazônia. MZUSP 93487 (202, 18.79-26.9mm SL), Pará, Pimental, rio Tapajós, $04^{\circ} 34^{\prime} 15$ 'S, 56 $6^{\circ} 15$ '39”'W, 11 Nov 2006 , L. M. Sousa \& J. L. Birindelli. MZUSP 97302 (36, 21.70-30.20 mm SL), Pará, Novo Progresso, rio Jamanxim, near Vila Mil, 23 Oct. 2007, J. L. Birindelli et. al. MZUSP 97431 (78, 26.20-29.40 mm SL),

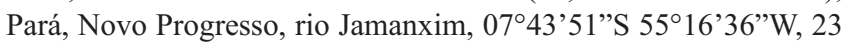
Oct 2007, J. L. Birindelli et al. MZUSP 102330 (105, 24.10-50.60 $\mathrm{mm}$ SL), Amapá, rio Jari, downstream of Cachoeira Santo Antônio, 0046'54”S, 52³1'48'W, 11 Oct 2007, M. Carvalho et.al. 


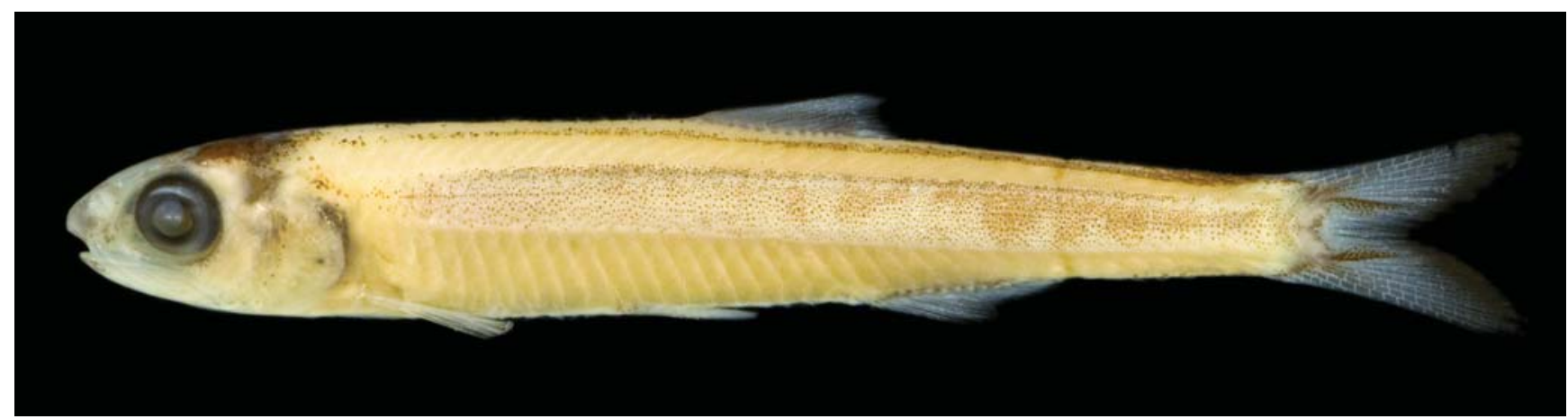

Fig. 1. Anchoviella juruasanga, holotype, MZUSP 15831, 42.4 mm SL, rio Trombetas, Trombetas, Pará State.

Diagnosis. Anchoviella juruasanga is distinguished from its congeners by having a short upper jaw, with its posterior tip extending between the verticals through anterior and posterior margins of the pupil ( $v s$. posterior tip of upper jaw extending beyond the vertical through posterior margin of the pupil). Anchoviella juruasanga is also distinct from other strictly freshwater Amazonian species of the genus by the distance from tip of snout to posterior end of upper jaw between 8 and $11 \%$ in SL (vs. $14 \%$ or more in A. alleni, A. carrikeri, A. guianensis, and $A$. jamesi). The anal-fin origin slightly posterior to or at the vertical through the base of the last dorsal-fin ray further distinguishes the new species from $A$. alleni (anal-fin origin posterior to the vertical through the last anal-fin ray by at least $14 \%$ of HL) and A. jamesi (anal-fin origin anterior to the vertical through the last anal-fin ray).

Description. Morphometric data of holotype and 40 paratypes is presented in Table 1. Body elongated, compressed laterally; greatest body depth at dorsal-fin origin. Dorsal body profile convex from snout tip to nostril, gently convex from nostril to dorsal-fin origin, approximately straight from latter point to caudal peduncle. Ventral body profile convex from anterior tip of lower jaw to posterior margin of orbit, gently convex from vertical through posterior margin of orbit to the posterior end of anal-fin base, nearly straight from latter point to the origin of lower caudal fin lobe. Caudal peduncle longer than deep. Vertebrae 39-40 (2 specimens examined).

Mouth inclined relative to body axis, sub-terminal, posterior tip of upper jaw rounded. Snout long, pointed in lateral view. Anterior tip of upper jaw distant from tip of snout by about 7.3 to $8.8 \%$ of HL. Posterior margin of upper jaw rounded, its posterior tip extending between the verticals through anterior and posterior margins of the pupil. Teeth pointed, small, slender, slightly recurved posteriorly, arranged in a single row in the premaxilla, maxilla and lower jaw.

Eye lateral on head, located dorsal to horizontal through pectoral-fin insertion; eye visible in dorsal and ventral views. Two confluent nostrils on each side of the head, the anterior elliptical and the posterior larger crescent-shaped. Lateral line absent.

Dorsal-fin rays ii-iii+11-12, origin closer to base of caudal fin than to tip of snout, not reaching the latter by 2.0 to $6.2 \%$ of SL, distal margin approximately straight. Anal-fin rays iiiii $+12-13$, its origin at vertical through base of last dorsal-fin ray, anterior rays longer. Pectoral-fin rays $i+11-13$, distal tip of longest pectoral-fin ray not reaching pelvic-fin origin by 6.0 to $13.0 \%$ of SL, distal margin slightly convex. Pectoralfin axillary scale absent in most specimens, probably lost during collecting or storage. Pelvic fin-rays $i+6$, distal tip of longest pelvic-fin ray not reaching anal-fin origin by 4.0 to

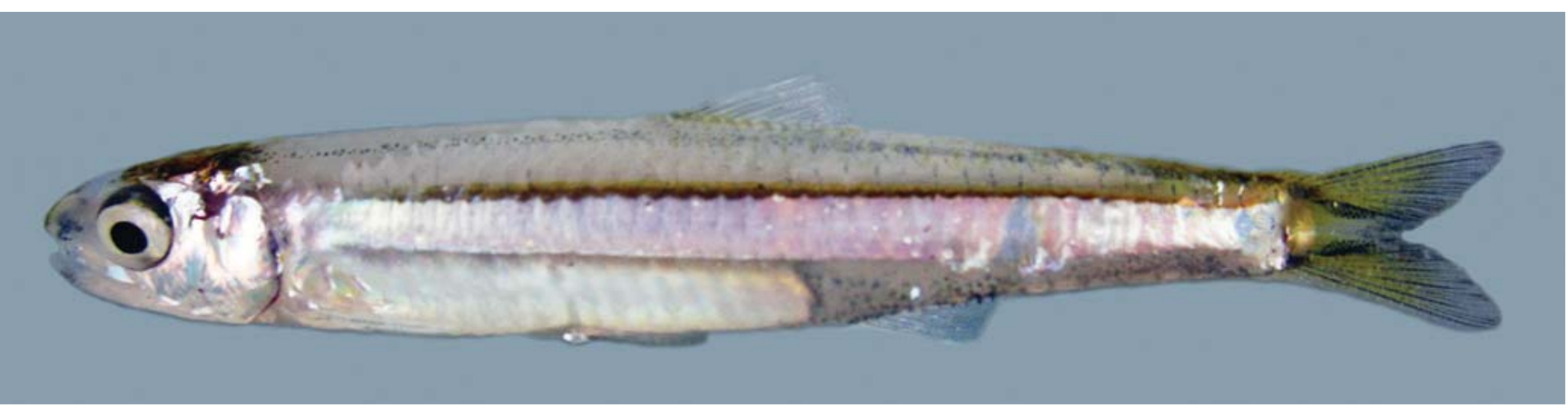

Fig. 2. Anchoviella juruasanga, freshly preserved specimen, MZUSP 103314, 46.0 mm SL, rio Jari, Monte Dourado, Pará State. Photo by J. L. Birindelli (MZUSP). 
$9.9 \%$ of SL, distal margin slightly convex. Pelvic-fin axillary scale absent in most specimens, probably lost during collecting or storage. Base of anteriormost pelvic-fin ray closer to anal-fin origin than to base of anteriormost pectoralfin ray, failing to reach the latter by about 2.6 to $4.8 \%$ of SL. Caudal fin forked, upper and lower lobes equally developed. Caudal-fin rays 5,10/10,5.

Pseudobranchia present, shorter than eye, approximately 18 to $23 \%$ of HL. Gill rakers long and thin in the first branchial arch, 8-12 on the upper branch, 16-22 on the lower branch, 25 to 34 in total. Length of raker inserted in the angle of first gill arch between $14-17 \%$ of HL.

Coloration in alcohol. Body coloration pale to light yellowish or brownish. Longitudinal stripe pale to silver, absent in most preserved specimens, when present extending from posterior margin of head to caudal peduncle; width of the stripe 10-20\% of $\mathrm{HL}$ at vertical through pectoral-fin origin, increasing posteriorly to $20-35 \%$ of HL at vertical through anal-fin origin. Dark spots present above and below the lateral stripe in some specimens, on top of the head, along the dorsum from origin of dorsal fin to caudal fin, along the ventrum, from origin of anal fin to caudal fin; also present along base of dorsal, anal, and caudal fins, and arranged in two vertical parallel stripes at caudal fin. Orbit and middle portion of the postorbital region in the head translucent to silver.

Coloration of freshly preserved specimens. Description of the coloration of freshly preserved specimens is based on a single specimen (MZUSP 103314, paratype, 46 mm SL; Fig. 2). Dorsum from the vertical through opercle to caudal fin above the longitudinal stripe translucent with dark spots; ventrum translucent from the vertical through opercle to caudal fin above the longitudinal stripe; posteriormost portion of upper and lower jaw and posteriormost portion of preorbital region also translucent. Dark spots present above the longitudinal stripe along body, on top of the head, along base of dorsal, anal and caudal fins, and also arranged in two vertical parallel stripes at caudal fin. Tip of upper and lower jaw, top of the head, base of dorsal and anal fins, above the longitudinal stripe, along the dorsum at caudal peduncle and at the anteriormost portion of caudal fin light yellowish. Postorbital region and longitudinal stripe along body silver, width of the stripe $25 \%$ of HL at vertical through pectoral-fin origin, increasing posteriorly to $30 \%$ of $\mathrm{HL}$ at vertical through anal-fin origin.

Etymology. In the Tupi language "juru" means mouth and "asanga" means short. The epithet juruasanga, thus, refers to the short maxilla, a diagnostic character of the species among congeners.

Distribution. Anchoviella juruasanga is known from tributaries of the middle and lower Amazon basin, Brazil, including rio Tapajós, rio Negro, rio Branco, rio Madeira, rio Trombetas, rio Tocantins, rio Maicá, and rio Jari (Fig. 3).

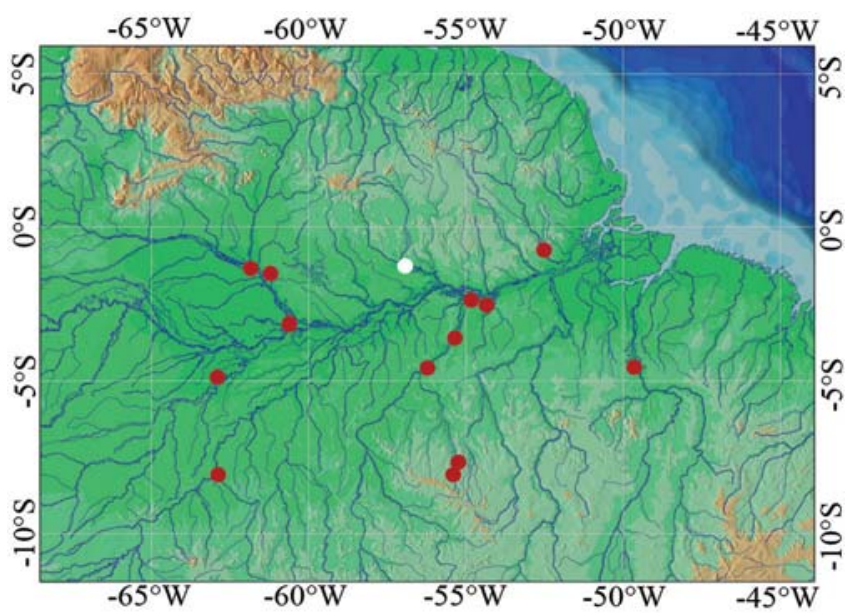

Fig. 3. Distribution map of Anchoviella juruasanga. Holotype indicated by white circle; paratypes and non-type material indicated by red circles.

Remarks. Anchoviella juruasanga is similar in terms of external morphology to A. jamesi and Amazonsprattus scintilla Roberts, 1984, which are paedomorphic engraulids known to co-occur with A. juruasanga in some rivers of the Amazon basin, such as the rio Jari. These three species share a short upper jaw, which, nevertheless, differs in terms of relative lengths. In $A$. jamesi the posterior tip of the upper jaw extends beyond the vertical through the posterior margin of the orbit by about $1 / 4$ the orbit diameter. The upper jaw of $A$. juruasanga is shorter than that of $A$. james $i$, with its posterior tip extending between the verticals through anterior and posterior margins of the pupil. In Amazonsprattus scintilla the upper jaw is extremely short compared to the condition typically present in the Engraulidae, and its posterior tip is located in a region anterior to the vertical through the anterior margin of the orbit (Whitehead et al., 1988). Another morphological difference between these three species is the relative position of the fins: in A. juruasanga the anal-fin origin is located in a region immediately posterior to the vertical through the base of the last dorsal-fin ray, whereas in Amazonsprattus scintilla and in A. jamesi the anal-fin origin is located at the vertical through the anterior quarter of the dorsal-fin base. The non-type material listed in the description was used in the color diagnosis, and also for inferring the distribution of the species.

\section{Identification key of Anchoviella from the Amazon basin.}

1a. Anal-fin origin at the vertical through base of last dorsalfin ray or posterior to it .... 2

1b. Anal-fin origin anterior to the vertical through base of last dorsal-fin ray..

2a. Posterior margin of upper jaw extending between the verticals through anterior and posterior margins of the pupil Anchoviella juruasanga 
2b. Posterior margin of upper jaw extending beyond the vertical through posterior margin of the pupil

3a. Number of rakers in the lower branch of first branchial arch 29-35; anal-fin rays 15-17 ......... Anchoviella cayenensis

3 b. Number of rakers in the lower branch of first branchial arch 19-25; anal-fin rays 17-22

4a. Anal-fin origin posterior to the vertical through base of last dorsal-fin ray by $14 \%$ or more of HL; upper jaw extending posteriorly beyond the posterior margin of the orbit by about 10 to $15 \%$ of HL Anchoviella alleni

4b. Anal-fin origin at vertical through base of last dorsal-fin ray or posterior to it by less than $10 \%$ of HL; upper jaw extending posteriorly beyond the posterior margin of the orbit by 7 to $11 \%$ or by 18 to $25 \%$ of HL

5a. Posterior margin of upper jaw extending beyond the vertical through posterior margin of orbit by $18-25 \%$ of HL Anchoviella carrikeri

5b. Posterior margin of upper jaw extending beyond the vertical through posterior margin of orbit by $7-11 \%$ of HL Anchoviella guianensis

6a. Anal-fin origin at the vertical through midpoint of dorsalfin base, or anterior to it .... 7

$6 \mathrm{~b}$. Anal-fin origin posterior to the vertical through midpoint of dorsal-fin base 7a. Number of rakers in the lower branch of first branchial arch 12-16; posterior margin of upper jaw extending beyond the vertical through posterior margin of orbit by $14-16 \%$ of HL Anchoviella sp. A

7b. Number of rakers in the lower branch of first branchial arch 18-25; posterior margin of upper jaw extending beyond the vertical through posterior margin of orbit by $16-21 \%$ of HL Anchoviella lepidentostole

8a. Lower jaw longer than upper jaw

8b. Upper jaw longer than lower jaw Anchoviella brevirostris

9a. Posterior margin of upper jaw extending under the vertica through posterior margin of orbit; number of rakers in the lower branch of first branchial arch 15-21

Anchoviellajamesi

$9 \mathrm{~b}$. Posterior margin of upper jaw extending beyond the vertical through posterior margin of orbit by $7-11 \%$ of $\mathrm{HL}$; number of rakers in the lower branch of first branchial arch $12-15$ Anchoviella sp. B

Comparative material. Amazonsprattus scintilla: MZUSP 92908 (71, 21.3-25.1 mm SL), Amazonas, igarapé Castanha, downstream Santa Rosa community, $00^{\circ} 05^{\prime} 26^{\prime}$ 'S 69³9'57'W, 28 Nov 2006, F. Lima. Anchoviella alleni: MZUSP 18485 (5, 68.3-75.35 mm

Table 1. Morphometrics and meristics of Anchoviella juruasanga $\mathrm{n}=$ number of examined specimens, $\mathrm{SD}=\mathrm{Standard}$ Deviation (frequency in parenthesis).

\begin{tabular}{|c|c|c|c|c|c|c|}
\hline & Hol otype & $\mathrm{n}$ & \multicolumn{2}{|c|}{ Range } & Mean & SD \\
\hline Standard length, SL (mm) & 42.4 & 41 & 19.3 & 51.5 & 34.00 & 10.00 \\
\hline Head length, HL (mm) & 10.8 & 41 & 5.2 & 12.4 & 8.37 & 2.22 \\
\hline \multicolumn{7}{|c|}{ Percentages of standard length } \\
\hline Body depth & 16.37 & 41 & 10.47 & 16.56 & 13.82 & 1.88 \\
\hline Caudal peduncle dep th & 8.36 & 41 & 7.05 & 9.13 & 8.03 & 0.57 \\
\hline Dorsal-fin base length & 11.21 & 41 & 11.01 & 14.81 & 12.57 & 1.10 \\
\hline Anal-fin base length & 11.50 & 41 & 11.08 & 15.98 & 13.09 & 1.31 \\
\hline Pelvic fin length & 10.81 & 41 & 8.81 & 13.13 & 10.79 & 1.06 \\
\hline Pectoral fin length & 14.42 & 41 & 9.73 & 14.99 & 13.06 & 1.45 \\
\hline Predorsal length & 53.38 & 41 & 49.42 & 55.43 & 52.21 & 1.63 \\
\hline Preanal length & 65.26 & 41 & 61.23 & 68.60 & 64.54 & 1.81 \\
\hline Prepelvic length & 44.47 & 41 & 42.47 & 47.90 & 45.07 & 1.43 \\
\hline Prepectoral len gth & 24.13 & 41 & 22.14 & 27.85 & 24.47 & 1.42 \\
\hline Pectoral-fin axillary s cale length & 8.36 & 30 & 3.45 & 11.31 & 6.93 & 2.19 \\
\hline Pelvic-fin axillary scale length & 4.03 & 16 & 2.70 & 6.64 & 4.03 & 1.09 \\
\hline Head length & 24.36 & 41 & 22.43 & 28.07 & 24.82 & 1.37 \\
\hline \multicolumn{7}{|c|}{ Percentages of head length } \\
\hline Snout length & 22.13 & 41 & 17.25 & 24.98 & 21.30 & 2.47 \\
\hline Orbital diameter & 32.96 & 41 & 29.20 & 36.66 & 31.49 & 2.18 \\
\hline Upper Jaw length & 46.92 & 41 & 40.24 & 47.95 & 44.01 & 2.73 \\
\hline Lower Jaw length & 46.00 & 41 & 43.33 & 49.93 & 46.93 & 2.13 \\
\hline Interorbital width & 22.31 & 41 & 19.04 & 26.55 & 22.48 & 2.47 \\
\hline Meristics & Hol otype & $\mathrm{n}$ & \multicolumn{4}{|c|}{ Range } \\
\hline Total dorsal-fin rays & 15 & 40 & \multicolumn{4}{|c|}{$13(4), 14(26), 15(10)$} \\
\hline Total anal-fin rays & 15 & 38 & \multicolumn{4}{|c|}{$14(7), 15(15), 16(16)$} \\
\hline Total pectoral-fin rays & 13 & 37 & \multicolumn{4}{|c|}{$12(8), 13(24), 14(5)$} \\
\hline Total pelvic-fin rays & 7 & 20 & \multicolumn{4}{|c|}{$7(20)$} \\
\hline Vertebrae & - & 2 & \multicolumn{4}{|c|}{$39(1), 40(1)$} \\
\hline \multicolumn{7}{|c|}{ Gill rackers on $1^{\text {st }}$ gill $\operatorname{arch}$} \\
\hline Upper branch & \multicolumn{2}{|c|}{11} & \multicolumn{4}{|c|}{$8(1), 9(7), 10(5), 11(7), 12(9)$} \\
\hline Lower branch & \multicolumn{2}{|l|}{21} & \multicolumn{4}{|c|}{$16(2), 17(4), 18(3), 19(7), 20(7), 21(5), 22(1)$} \\
\hline Total & \multicolumn{2}{|l|}{32} & \multicolumn{4}{|c|}{$25(3), 26(2), 27(3), 28(2), 29(2), 30(4), 31(4), 32(4), 33(4), 34(1)$} \\
\hline
\end{tabular}


SL), Peru, rio Ucayali, Masisea, 24 Sep 1974, H. Ortega. Anchoviella brevirostris: MZUSP 11574 (1, $68.6 \mathrm{~mm} \mathrm{SL})$, Bahia, rio Paraguassú, Maragogipe, 13 Oct 1971, A.V. Alcântara. Anchoviella carrikeri: MZUSP 29114 (36, 18.03-26.34), Amazonas, rio Negro, Barcelos, AM, 9 Feb 1980, M. Goulding. Anchoviella cayenesis: MZUSP 11579 (1, 86.4 mm SL), Sergipe, Aracaju, Jul 1961, N. Menezes. Anchoviella guianensis: MZUSP

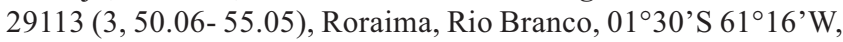
28 Oct 1979, M. Goulding. Anchoviella jamesi: MZUSP 29093 (4, 47.68-50.20 mm SL), Amazonas, rio Tefé, Jurupari, 03²2'S 6443'W, 1 Aug 1979, M. Goulding. Anchoviella lepidentostole: MZUSP 11576 (2, 39.30-47.10 mm SL), Bahia, Ilhéus, Malhado and Malhadinho Beach, 25-26 Oct 1971, A.V. Alcântara.

\section{Acknowledgements}

This article is part of my M.Sc. thesis, advised by J. L. Figueiredo (MZUSP) and funded by FAPESP (09/737377-4). I thank M. Toledo-Piza (IBUSP) and F. Di Dario (UFRJ), members of my thesis committee. Thanks are also due to L. Py-Daniel (INPA) for the loan of specimens. Rodrigo Caires and U. Martins (MZUSP) helped me to choose the name of the species. Gareth Nelson (University of Melbourne, Australia), J. Birindelli (MZUSP), M. Marinho (MZUSP) and an anonymous reviewer provided insightful comments to the manuscript. Henrique Varella and J. Birindelli helped with photographs and preparation of figures.

\section{Literature Cited}

Cervigón, F. 1982. La ictiofauna estuarina del Caño Manamo y areas adyacentes. Pp. 205-260. In: Daniel Novoa, R. (Ed.). Los recursos pesqueros del Rio Orinoco y su explotacion. Venezuela, $386 \mathrm{p}$.

Di Dario, F. 2009. Chirocentrids as engrauloids: evidence from suspensorium, branchial arches, and infraorbital bones (Teleostei, Clupeomorpha). Zoological Journal of the Linnean Society, 156: 363-383.

Eschmeyer, W. N. \& R. Fricke. 2012. Catalog of Fishes electronic version (01 Feb. 2012). http://research.calacademy.org/research/ ichthyology/catalog/fishcatmain.asp

Fowler, H. W. 1911. Notes on clupeoid fishes. Proceedings of the Academy of Natural Science of Philadelphia, 63: 204-221.

Hildebrand, S. F. 1943. A review of the American anchovies (family Engraulidae). Bulletin of the Bingham Oceanographic Collection of Yale University, 8: 1-165.

Jordan, D. S. \& A. Seale. 1925. Analysis of the genera of anchovies or Engraulidae. Copeia, 1925: 27-32.

Jordan, D. S. \& A. Seale. 1926. Review of the Engraulidae, with descriptions of new and rare species. Bulletin of the Museum of Comparative Zoology, 67: 353-418.

Kullander, S. O. 2003. Engraulididae. Pp. 39-42. In: Reis, R. E., S. O. Kullander \& C. J. Ferraris. (Eds.). Check list of the freshwater fishes of South and Central America. Edipucrs, Porto Alegre, $729 \mathrm{p}$.

Loeb. M. V. 2009. Revisão taxonômica das espécies do gênero Anchoviella Fowler, 1911 (Clupeiformes, Engraulidae) das bacias Amazônica e do São Francisco. Unpublished M.Sc. Dissertation, Universidade de São Paulo, São Paulo, 97p.
Menezes, N. A. \& J. L. Figueiredo. 2003. Family Engraulidae. Pp. 38-40. In: Menezes, N. A., P. A. Buckup, J. L. Figueiredo \& R. L. Moura. (Eds). Catálogo das espécies de peixes marinhos do Brasil. Museu de Zoologia da Universidade de São Paulo, São Paulo, 160p.

Myers, G. S. 1940. The neotropical anchovies of the genus Amplova. Proceedings of the California Academy of Sciences, 23: 437-442.

Nelson, J. S. 2006. Fishes of the World. John Wiley \& Sons, New Jersey, 601p.

Taylor, W. R. \& G. C. van Dyke. 1985. Revised procedures for staining and clearing small fishes and other vertebrates for bone and cartilage study. Cybium, 9: 107-119.

Whitehead, P. J. P. 1985. FAO species catalog. Clupeoid fishes of the world (suborder Clupeoidei). Part 1 - Chirocentridae, Clupeidae and Pristigasteridae. FAO Fisheries Synopsis, 7: 1-304.

Whitehead, P. J. P., G. J. Nelson \& T. Wongratana. 1988. FAO species catalogue. Clupeoid fishes of the world (Suborder Clupeoidei). An annotated and illustrated catalogue of the herrings, sardines, pilchards, sprats, shads, anchovies and wolf-herrings. Part 2 Engraulididae. FAO Fisheries Synopsis, 7: 305-579.

Submitted August 3, 2011

Accepted February 3, 2012

Published March 30, 2012 